\title{
Exploitation of a chemosynthetic food resource by the polychaete Capitella sp. I
}

\author{
Hiroaki Tsutsumi ${ }^{1, *}$, Sam Wainright ${ }^{2}$, Shigeru Montani ${ }^{3}$, Megumi Saga1, $^{1}$ \\ Sagiri Ichihara ${ }^{1}$, Kazuhiro Kogure ${ }^{4}$ \\ ${ }^{1}$ Faculty of Environmental and Symbiotic Sciences, Prefectural University of Kumamoto, 3-1-100 Tsukide, Kumamoto 862, Japan \\ ${ }^{2}$ US Coast Guard Academy, 15 Mohegan Avenue, New London, Connecticut 06320-8100, USA \\ ${ }^{3}$ Faculty of Agriculture, Kagawa University, Ikedo, Kida-gun, Kagawa-ken 761-07, Japan \\ ${ }^{4}$ Ocean Research Institute, Tokyo University, 1-15-1 Minamidai, Shinjuku-ku, Tokyo 164, Japan
}

\begin{abstract}
In organically enriched sediments of coastal areas, sulfate-reducing bacteria decompose organic matter anaerobically, producing high levels of hydrogen sulfide. Chemoautotrophic sulfur-oxidizing bacteria proliferate at the sulfide/oxygen interface and use hydrogen sulfide as an electron donor. A few species of small polychaete worms, including Capitella sp. I, often dominate the macrofaunal benthic communities in such sulfide-rich environments in the organically enriched sediments. In this study, we conducted 2 laboratory experiments to determine whether Capitella sp. I can benefit trophically through the exploitation of the organic matter chemosynthetically produced by sulfur-oxidizing bacteria. In the first experiment, we reared juveniles of Capitella sp. I with natural sediment of very low organic content, with no additional organic matter, under dark conditions, and exposed them to 3 different levels of sodium sulfide. The worms reared in the sulfide treatments showed better survival, enhanced growth and reproduction. They had lower $\delta^{13} \mathrm{C}$ values $(-24.3 \%$, mean) than control worms $(-20.1 \%$, mean) and the sediments in which the worms were cultured $\left(-21.4 \%\right.$, mean). The distinctive $\delta^{13} \mathrm{C}$ signature of the worms in the sulfide treatments indicates that they did not share the same carbon source as the control worms. The second experiment was done in the same manner as the first, but the carbonate in the water was replaced with ${ }^{13} \mathrm{CO}_{2}$ in order to trace the autotrophic fixation of carbon dioxide by chemosynthetic bacteria occurring within the sediments. The results indicate that fixation of ${ }^{13} \mathrm{CO}_{2}$ was promoted in sediments with $\mathrm{Na}_{2} \mathrm{~S}$ amendments, and further enhanced by the presence of Capitella sp. I. The worms in these sediments had extremely high $\delta^{13} \mathrm{C}$ values $(+5218.2 \%$ ). The results of this study introduce the possibility of enhanced survival and growth of Capitella sp. I in sulfide-rich environments in the organically enriched sediments, facilitated by its utilization of a novel source of organic matter.
\end{abstract}

KEY WORDS: Capitella $\cdot$ Chemoautotrophic bacteria $\cdot$ Stable isotope $\cdot$ Organic enrichment $\cdot{ }^{13} \mathrm{C} \cdot{ }^{15} \mathrm{~N}$

\section{INTRODUCTION}

The species composition of macrobenthic communities throughout the world is strongly dependent upon the sedimentary organic content. In organically enriched sediments, macrobenthic communities tend to be domi-

*E-mail: hiro@pu-kumamoto.ac.jp nated by only a few species of small annelids including the polychaetes, Capitella sp. I (Grassle \& Grassle 1976), other members of the Capitella complex, and spionids, while more diverse communities that include molluscs, crustaceans and echinoderms may predominate in sediments that are less organically enriched (Reish 1971, 1979, Kitamori 1975, Pearson \& Rosenberg 1976, 1978).

Previous studies on the association between Capitella species and organically enriched sediments were con- 
cerned with 'physiological tolerance to the low oxygen conditions' in organically enriched sediments (Reish 1970) and 'life-history adaptations' (Grassle \& Grassle 1974). The reasons for Capitella spp.s' association with organically enriched sediments still are not entirely clear, although it has been shown experimentally that their larvae may choose organic-rich mud over sand at the time of settlement and metamorphosis (Butman \& Grassle 1992, Grassle et al. 1992). Our laboratory experiments (Tsutsumi et al. 1990) and others (Tenore 1983, Alongi \& Tenore 1985) have shown that growth of these Capitella species is independent of sedimentary organic content, but is correlated with the amount of labile organic matter.

Our field work on the population dynamics of Capitella sp. (Tsutsumi 1987, 1990) revealed that the populations occurring on the tidal flat, and below a fish culture net pen, were severely reduced during the summer, following the development of reducing conditions in the organically enriched sediments, but that tiny patches (with extremely low densities) remained in the less organically enriched sediments within the habitats. When the surface of the organically enriched sediments was oxidized, the remnant patches soon recolonized and exhibited a large potential for population growth. Large, dense patches of over 40000 individuals $\mathrm{m}^{-2}$ were re-established within only 2 to $3 \mathrm{mo}$. This rapid growth process was reproduced in organically enriched sediments under experimental conditions (Bridges et al. 1994, Levin et al. 1996). These studies clarified the demographic processes associated with the rapid population growth (e.g. fast individual growth, early maturation, and increased fecundity per brood). Field work and laboratory studies seem to suggest that the Capitella species favor organically enriched sediments as a temporary habitat (in which a large amount of labile organic matter, essential to their rapid population growth, is available).

Over the past 2 decades, much has been learned about the abundant benthic communities around hydrothermal vents in the deep sea, where high levels of hydrogen sulfide support primary production by chemoautotrophic sulfur-oxidizing bacteria (Corliss et al. 1979, Rau 1981, Grassle 1985, Tunnicliffe et al. 1985, Hashimoto et al. 1993). Recently, a Capitella species and other capitelid polychaetes also have been found around shallow hydrothermal vents in sulfiderich conditions in the Mediterranean Sea (Kamenev et al. 1993, Dando et al. 1995, Thiermann et al. 1997). The Capitella species, which is referred to as Capitella sp. M, possesses a similar life history to Capitella sp. I (e.g. short life cycle, production of free-swimming larvae), but exhibits a higher tolerance to hypoxia and high-sulfide conditions (Gamenick et al. 1998b). Gamenick et al. (1998a) measured high sulfide levels (approximately 300 to $1400 \mu \mathrm{M}$ ) in sediments inhabited by Capitella sp. M close to vent outlets. Capitella sp. M demonstrated a high tolerance for hydrogen sulfide $(740 \mu \mathrm{M}$ in anoxic conditions), suggesting the possibility that organic matter produced chemosynthetically by sulfur-oxidizing bacteria may be available for use by Capitella species.

Similar sulfide-rich environments exist in the organically enriched sediments of estuaries and on mud flats, where sulfate-reducing bacteria decompose organic matter anaerobically, releasing hydrogen sulfide as a byproduct (Jørgensen \& Fenchel 1974, Jørgensen 1977a,b, Martens 1984). In these shallow-water environments, the presence of symbiotic chemoautotrophic bacteria able to exploit hydrogen sulfide as a source of energy has been reported in some benthic species, including bivalves, vestimentiferans, pogonophores, and oligochaetes (Felbeck et al. 1983, Cavanaugh 1985, Vetter 1985, Giere et al. 1988, Fenchel \& Findlay 1989, Schmaljohann et al. 1990). Although Capitella species do not harbor endosymbiotic bacteria (Felbeck et al. 1981, Cuomo 1985), it is possible that they may benefit trophically from the additional supply of labile organic matter produced by chemosynthetic bacteria in organically enriched sediments.

Another question that has not been adequately addressed is how Capitella species maintain themselves in sediments of low organic content between periods when organically rich sediments become available. It is possible that Capitella spp. exist at extremely low densities in sediments of low organic content, living suboptimally, but nevertheless producing small numbers of larvae (Grassle \& Grassle 1974, 1976, Tsutsumi \& Kikuchi 1984, Tsutsumi 1990). In such sediments with low organic content, chemosynthetically produced organic matter may be available around the redox potential discontinuity layer, the interface between oxic and reduced conditions where sulfur-oxidizing bacteria may thrive (Nelson 1992).

In the present study, we conducted 2 laboratory experiments to determine whether Capitella sp. I can exploit chemosynthetically produced organic matter. In Expt 1, we reared juvenile Capitella sp. I in natural sediment of very low organic content, with no external supply of organic matter, and under dark conditions. The cultures were exposed to 3 different levels of AVS (acid-volatile sulfide). We measured the body sizes of the worms, determined carbon and nitrogen stable-isotope ratios of both the sediment and worms, and examined whether Capitella sp. I could grow and complete its life cycle. In Expt 2, we reared Capitella sp. I juveniles in the same manner as in Expt 1, but we enriched the carbonate in the water with ${ }^{13} \mathrm{C}$. We determined carbon and nitrogen stable-isotope ratios of the sediment and worms and examined how much 
inorganic ${ }^{13} \mathrm{C}$ in the water was incorporated into the organic matter of the sediment through chemosynthesis by sulfur-oxidizing bacteria and then assimilated by the worms through their feeding on the sediment.

The goal of this study was to clarify whether Capitella sp. I growing in the presence of sulfide can exploit chemosynthetically produced organic matter as one of the sources of available organic matter.

\section{MATERIALS AND METHODS}

The culture of Capitella sp. I (Grassle \& Grassle 1976) maintained in our laboratory was originally established using worms collected from Tomoe Cove, Amakusa, Japan. Identity was confirmed by crossbreeding with known Capitella sp. I (J. P. Grassle pers. comm.). Mud for use in the laboratory experiments was collected from Hiketa Bay, Seto Inland Sea, Japan (siltclay content $=84.4 \%$, total organic carbon and nitrogen contents $=2.06$ and $0.21 \%$, respectively). The mud was frozen at $-20^{\circ} \mathrm{C}$, thawed, and homogenized with a spatula (stirring for $1 \mathrm{~min}$ ) before experiments. Sea water was filtered with membrane filters (Advantec, cellulose nitrate $0.45 \mu \mathrm{m}$ ) and glass-fiber filters (Advantec, GC50). Plastic containers $(20 \times 30 \times 10 \mathrm{~cm})$ were filled with $1.5 \mathrm{~kg}$ of mud (sediment depth $=2 \mathrm{~cm}$ ) and $2 \mathrm{l}$ of filtered sea water.

Expt 1 (Table 1). We collected 300 brood tubes of Capitella sp. I from the laboratory culture and isolated them individually in petri dishes with sea water. We collected daily the free-swimming larvae that hatched out from the brood tubes and kept the larvae in a flask with sea water. Six experimental containers were prepared. To each of them, $500 \mathrm{~d}$ old free-swimming larvae were added. The larvae soon settled on the substrate in these containers and metamorphosed to juveniles. The 6 containers were kept in the dark at $20^{\circ} \mathrm{C}$. Water in the containers was gently aerated. The worms were exposed to 2 different levels of sulfide by adding 0.1 and $0.2 \mathrm{~g}$ of sodium sulfide crystals $\left(\mathrm{Na}_{2} \mathrm{~S} \cdot 9 \mathrm{H}_{2} \mathrm{O}\right)$ to $30 \mathrm{ml}$ sea water (low- and high-sulfide treatments, respectively), plus 1 control to which no sulfide was added. These solutions $(13.9 \mathrm{mM}$ in low-

Table 1. Expt 1. Concentrations of acid-volatile sulfide (AVS) of sediments and percent survival of worms after $6 \mathrm{wk}$

\begin{tabular}{|c|c|c|c|c|c|c|}
\hline & \multirow[b]{2}{*}{ Control-1 } & \multirow[b]{2}{*}{ Control-2 } & \multicolumn{2}{|c|}{ - Treatment } & \multirow[b]{2}{*}{$\begin{array}{c}\text { High } \\
\text { sulfide-1 }\end{array}$} & \multirow[b]{2}{*}{$\begin{array}{c}\text { High } \\
\text { sulfide-2 }\end{array}$} \\
\hline & & & $\begin{array}{c}\text { Low } \\
\text { sulfide-1 }\end{array}$ & $\begin{array}{c}\text { Low } \\
\text { sulfide-2 }\end{array}$ & & \\
\hline $\begin{array}{l}\text { AVS of sediment } \\
\quad\left(\mathrm{mg} \mathrm{g}^{-1} \text { dry sedir }\right.\end{array}$ & $\begin{array}{r}0.39 \\
\text { iment) }\end{array}$ & 0.45 & 0.53 & 0.65 & 0.67 & 0.79 \\
\hline Survival \% & 40.6 & 57.6 & 70.6 & 74.2 & 62.4 & 65.8 \\
\hline
\end{tabular}

sulfide treatments, $27.8 \mathrm{mM}$ in high-sulfide treatments) were gently injected into the sediments twice daily, beginning $3 \mathrm{~d}$ after the start of the experiments. In the control containers, unamended sea water was injected in the same manner. Each treatment was duplicated. The experiment lasted $6 \mathrm{wk}$. At the end of the experiment, 3 sediment cores (diam. $=36 \mathrm{~mm}$ ) were taken from each container. One was used to determine AVS levels (Gastec, No. 201H) and stableisotope ratios $\left(\delta^{13} \mathrm{C}\right.$ and $\left.\delta^{15} \mathrm{~N}\right)$ of the sedimentary organic matter. The latter were determined on a Finnigan Delta-S stable-isotope mass spectrometer coupled to a Heraeus elemental analyzer through a Finnigan cryogenic gas-trapping box. Sediments were treated with dilute $\mathrm{HCl}$ prior to analysis to remove carbonates and then dried $\left(50^{\circ} \mathrm{C}\right)$. The other 2 cores were fixed in $10 \%$ formalin solution containing Rose Bengal dye and sieved on a $125 \mu \mathrm{m}$ mesh. The worms were counted and the maximum widths of the thoracic segments (cf. Tsutsumi \& Kikuchi 1984) were measured with a stereoscopic microscope image-analysis system. This system included a CCD (charged-coupled device) camera (Sony, DXC-930) on a microscope (Olympus, SZH), a personal computer (Apple Macintosh, Quadra 700) with a frame-grabber card (Data Translation, QuickCapture), and image-analysis software (NIH Image Version 1.55).

The remaining sediment in each container was sieved on a $125 \mu \mathrm{m}$ sieve. The worms were removed and maintained in individual petri dishes with sea water until they had excreted all faecal pellets. The worms were then dried at $50^{\circ} \mathrm{C}$, ground to a fine powder, and their stable-isotope compositions determined.

Expt 2 (Table 2). This experiment utilized additions of $\mathrm{Na}_{2}{ }^{13} \mathrm{CO}_{3}$ to the water in the culture containers in a dark environment to demonstrate the fixation of $\mathrm{CO}_{2}$ by chemoautotrophic bacteria within the sediment. Water (19.6 l) was sparged with $\mathrm{N}_{2}$ gas for $24 \mathrm{~h}$, removing a portion of the dissolved inorganic carbon from the water. The sparged water was then equally divided into 2 capped beakers. Then, $2.3 \mathrm{~g}$ of $\mathrm{Na}_{2} \mathrm{CO}_{3}$ containing $99 \%{ }^{13} \mathrm{C}$ (Isotech, Inc.) was added to 1 beaker of sparged water, while the other received an equivalent amount of $\mathrm{Na}_{2} \mathrm{CO}_{3}$ with natural isotopic abundance. Both beakers were then thoroughly shaken.

Two sets of experimental containers were prepared. One set of 4 containers (Group 1: A-D) contained sea water of natural isotopic abundance. The second set of 4 containers (Group 2: A-D) contained $\quad 99 \% \quad \mathrm{Na}_{2}{ }^{13} \mathrm{CO}_{3}$ sea water. Each was treated as follows: $\mathrm{A}$ and $\mathrm{C}$ containers had no 
Table 2. Expt 2. Experimental conditions of 4 containers in Treatment Groups 1 and 2

\begin{tabular}{|c|c|c|c|c|c|c|c|c|}
\hline & \multicolumn{4}{|c|}{ Group 1} & \multicolumn{4}{|c|}{ - Group 2 - } \\
\hline & $\mathrm{A}$ & B & $\mathrm{C}$ & $\mathrm{D}$ & A & B & $\mathrm{C}$ & $\mathrm{D}$ \\
\hline $\begin{array}{l}\text { Sodium carbonate } \\
\text { added to the water }\end{array}$ & Natural & Natural & Natural & Natural & $99 \%{ }^{13} \mathrm{C}$ & $99 \%{ }^{13} \mathrm{C}$ & $99 \%{ }^{13} \mathrm{C}$ & $99 \%{ }^{13} \mathrm{C}$ \\
\hline $\begin{array}{l}\text { Daily dosing of } \\
\text { sodium sulfide }\end{array}$ & None & None & $0.2 \mathrm{~g}$, twice & $0.2 \mathrm{~g}$, twice & None & None & $0.2 \mathrm{~g}$, twice & $0.2 \mathrm{~g}$, twice \\
\hline $\begin{array}{l}\text { Initial no. of } \\
\quad \text { Capitella sp. I larvae }\end{array}$ & None & 500 & None & 500 & None & 500 & None & 500 \\
\hline
\end{tabular}

Capitella sp. I; B and D containers had 500 individual Capitella sp. I larvae; A and B containers did not receive daily sulfide treatments; $C$ and $D$ containers received sulfide treatments.

The experiment lasted for $8 \mathrm{wk}$. Sulfide was administrated twice daily by the injection of $0.2 \mathrm{~g} \mathrm{Na}_{2} \mathrm{~S}$ per $10 \mathrm{ml}$ seawater solution into the sediment. Incubation temperature was $15^{\circ} \mathrm{C}$. The water in the culture containers was exchanged weekly. The $\delta^{13} \mathrm{C}$ of the sediments and Capitella sp. I was determined with a Europa Scientific ANCA-GSL elemental analyzer coupled with a Europa 20-20 stable-isotope ratio-mass spectrometer in continuous-flow mode. All other analytical procedures were identical to those in Expt 1.

\section{RESULTS}

\section{Expt 1}

AVS and survival

Table 1 shows the levels of AVS within the sediments and the percent survival of Capitella sp. I after 6 wk. AVS includes hydrogen sulfide and metal sulfides. Even in the controls, where we did not add $\mathrm{Na}_{2} \mathrm{~S}$ solution to the sediments, AVS was present at concentrations of 0.39 and $0.45 \mathrm{mg} \mathrm{g}^{-1}$ dry sediment. The AVS levels of the sediments increased proportionally with increasing concentrations of $\mathrm{Na}_{2} \mathrm{~S}$ solution injected into the sediments $\left(0.53\right.$ and $0.65 \mathrm{mg} \mathrm{g}^{-1}$ dry sediment in the low-sulfide treatments, 0.67 and $0.79 \mathrm{mg} \mathrm{g}^{-1}$ dry sediment in the high-sulfide treatments). The elevated AVS levels in the 2 sulfide treatments caused no apparent negative effects on the survival of the worms. In fact, the survival rates were highest in the low-sulfide containers (70.6 and 74.2\%) and were higher in both of the sulfide treatments than in the controls (40.6 and 57.6\%). However, the difference in survival between treatments was not statistically significant (Welch's $t$-test, $t[0.975]=12.70$, $\mathrm{p}=0.28)$.
Growth

When Capitella sp. I larvae settle onto the sediment, the maximum thoracic width is approximately $0.15 \mathrm{~mm}$ (cf. Tsutsumi \& Kikuchi 1984, Tsutsumi 1987). After $6 \mathrm{wk}$, distinct differences in worm size were observed between the controls and the sulfide treatments (Figs. 1 \& 2). In the controls, the mean maximum thoracic width of the worms was less than $0.3 \mathrm{~mm}$, and no worms exhibited signs of sexual maturity (development of genital hooks in males and ovaries in females). In the low- and high-sulfide treatments, the mean maximum thoracic widths were 0.53 to $0.58 \mathrm{~mm}$. These differences in body size between the controls and the sulfide treatments were statistically significant (ANOVA, $\mathrm{p}<0.01$ ). This species becomes sexually mature when the maximum thoracic width is 0.4 to $0.5 \mathrm{~mm}$ (Tsutsumi \& Kikuchi 1984, Tsutsumi 1987). In the sulfide treatments, some worms had already

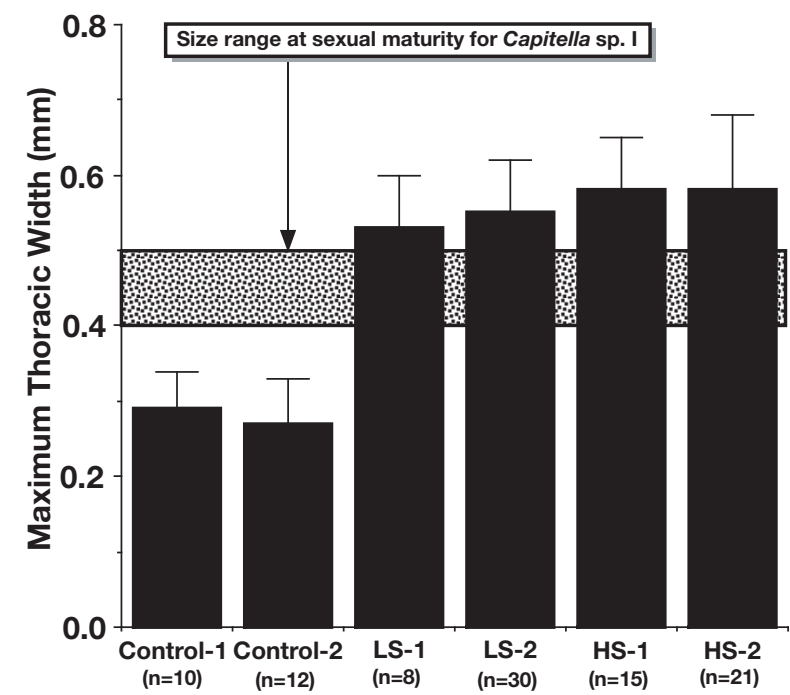

Fig. 1. Capitella sp. I. Body size, as maximum width of thoracic segments, after $6 \mathrm{wk}$, in duplicates of 3 treatments $(\mathrm{n}=$ total number of worms captured in 2 cores, surface area $=10.2 \mathrm{~cm}^{2}$, taken from each container). LS: low sulfide; HS: high sulfide 


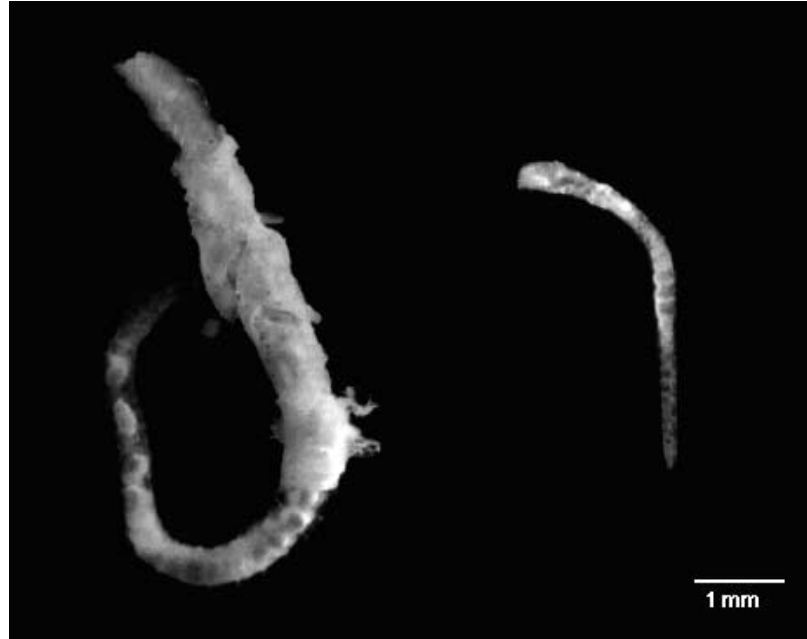

Fig. 2. Capitella sp. I. Fixed specimens after 6 wk. Right: control juvenile, $0.32 \mathrm{~mm}$ max. thoracic width; left: high-sulfide treatment female in a brood tube, $0.58 \mathrm{~mm}$ max. thoracic width

reproduced. We collected brooding females with brood tubes from the high-sulfide treatments (Fig. 2).

\section{Stable isotopes}

Table 3 shows the results of the stable-isotope analysis of the sediments and the worms. Prior to the start of the experiment, the $\delta^{13} \mathrm{C}$ and $\delta^{15} \mathrm{~N}$ values of the sediments were -21.7 and $+8.7 \%$, respectively. After $6 \mathrm{wk}$, $\delta^{13} \mathrm{C}$ values ( -21.4 to $-21.2 \%$ ) were slightly enriched in the sediments in all 3 treatments ( 0.3 to $0.5 \%$ higher than initial). Distinct carbon-isotope differences were

Table 3. Expt 1. Carbon and nitrogen isotope ratios $\left(\delta^{13} \mathrm{C}, \delta^{15} \mathrm{~N}\right)$ of sediments and Capitella sp. I. Asterisk indicates single measurement, others are mean of 2 measurements

\begin{tabular}{|c|c|c|c|c|c|c|}
\hline & \multicolumn{6}{|c|}{ — Treatment } \\
\hline & Control-1 & Control-2 & $\begin{array}{c}\text { Low } \\
\text { sulfide-1 }\end{array}$ & $\begin{array}{c}\text { Low } \\
\text { sulfide-2 }\end{array}$ & $\begin{array}{c}\text { High } \\
\text { sulfide-1 }\end{array}$ & $\begin{array}{c}\text { High } \\
\text { sulfide-2 }\end{array}$ \\
\hline \multicolumn{7}{|c|}{$\delta^{13} \mathrm{C}$ of bulk sediment } \\
\hline Initial & -21.7 & -21.7 & -21.7 & -21.7 & -21.7 & -21.7 \\
\hline 6 wk later & -21.3 & -21.2 & -21.2 & -21.2 & -21.3 & -21.4 \\
\hline $\begin{array}{c}\delta^{13} \mathrm{C} \text { of worms } \\
6 \text { wk later }\end{array}$ & $-20.2^{*}$ & -19.9 & $-22.0^{*}$ & $-21.7^{*}$ & -25.1 & $-23.6^{*}$ \\
\hline Worms-sediment & +0.9 & +1.3 & -0.8 & -0.5 & -3.8 & -2.2 \\
\hline \multicolumn{7}{|c|}{$\delta^{15} \mathrm{~N}$ of bulk sediment } \\
\hline Initial & +8.7 & +8.7 & +8.7 & +8.7 & +8.7 & +8.7 \\
\hline 6 wk later & +8.1 & +8.5 & +8.6 & +8.3 & +7.9 & +9.7 \\
\hline $\begin{array}{c}\delta^{15} \mathrm{~N} \text { of worms } \\
6 \mathrm{wk} \text { later }\end{array}$ & +10.7 & +10.1 & +12.3 & +12.4 & +10.4 & +11.2 \\
\hline Worms-sediment & +2.6 & +1.6 & +3.7 & +4.1 & +2.5 & +1.5 \\
\hline
\end{tabular}

found among worms from the 3 experimental treatments. The 2 sets of control worms were isotopically enriched relative to the sediment (by 0.9 and $1.3 \%$ in $\delta^{13} \mathrm{C}$ ). In contrast, worms in the low-sulfide treatments were depleted ( 0.8 and $0.5 \%$ ) and were $1.8 \%$ depleted relative to the control worms. Worms in the high sulfide treatments were 3.8 and $2.2 \%$ depleted relative to the sediment.

The $\delta^{15} \mathrm{~N}$ values of the sediments were slightly depleted in the controls $(-0.4 \%$ o) and in the low-sulfide treatments $(-0.2 \%$ ) relative to initial values and were slightly enriched in the high-sulfide treatments (+0.1\%). Worms were enriched in ${ }^{15} \mathrm{~N}$ relative to the sediments by 2.0 to $2.9 \%$ in all 3 treatments.

\section{Expt 2}

Worm growth rates and AVS levels were similar to those found in Expt 1, with a significant enhancement of growth in the treatments that received sulfide additions (see Treatments 1-D and 2-D in Table 4). In treatments to which unlabeled sodium carbonate (Group 1) had been added to the sea water, the carbon and nitrogen isotopic signatures of the sediments were relatively invariant throughout the experiments. However the worms in Treatment 1-D (with sulfide) that grew to adulthood were depleted in ${ }^{13} \mathrm{C}$ relative to the sediment 8 wk later $\left(-2.3 \%\right.$ in $\left.\delta^{13} \mathrm{C}\right)$, a similar depletion to that seen in Expt 1 (Table 3).

In Group 2, which received ${ }^{13} \mathrm{C}$ amendments, the sediments were enriched in ${ }^{13} \mathrm{C}$, presumably due to bacterial chemosynthesis. The fixation of ${ }^{13} \mathrm{CO}_{2}$ within the sediments was markedly enhanced by the presence of $\mathrm{Na}_{2} \mathrm{~S}$ (Treatments 2-C, 2-D) and was further enhanced by the presence of Capitella sp. I (Treatment 2-D). The carbon-isotope signature of the worms in Treatment 2-D reached $+5218.2 \%$ after 8 wk. This extreme ${ }^{13} \mathrm{C}$ enrichment in the worms compared with the sediment $\left(+258.7 \%\right.$ in $\delta^{13} \mathrm{C}$ after $8 \mathrm{wk}$ ) suggests that the enhanced growth of the worms in the sulfide treatments relied on the selective ingestion of chemosynthetically produced organic matter from the sediments.

\section{DISCUSSION}

In Expt 1, control Capitella sp. I showed a relatively high mortality 
Table 4. Expt 2. Acid-volatile sulfide (AVS) of sediments, growth of Capitella sp. I, and carbon and nitrogen isotope ratios $\left(\delta^{13} \mathrm{C}, \delta^{15} \mathrm{~N}\right)$ of sediments and worms. All results are means of 2 measurements

\begin{tabular}{|c|c|c|c|c|c|c|c|c|}
\hline & \multirow[b]{2}{*}{$1-\mathrm{A}$} & \multirow[b]{2}{*}{$1-\mathrm{B}$} & \multirow[b]{2}{*}{$1-\mathrm{C}$} & \multicolumn{2}{|c|}{ - Treatment } & \multirow[b]{2}{*}{$2-B$} & \multirow[b]{2}{*}{$2-\mathrm{C}$} & \multirow[b]{2}{*}{$2-\mathrm{D}$} \\
\hline & & & & $1-\mathrm{D}$ & $2-\mathrm{A}$ & & & \\
\hline AVS after $8 \mathrm{wk}$ & 0.01 & 0.01 & 0.27 & 0.33 & 0.02 & 0.00 & 0.21 & 0.19 \\
\hline $\begin{array}{l}\text { Mean body size (mm) } \\
\text { (max. width of } \\
\text { thoracic segments) }\end{array}$ & - & 0.16 & - & 0.41 & - & 0.14 & - & 0.55 \\
\hline \multicolumn{9}{|l|}{$\delta^{13} \mathrm{C}$ of sediment } \\
\hline $\begin{array}{l}2 \text { wk later } \\
4 \text { wk later } \\
6 \text { wk later } \\
8 \text { wk later }\end{array}$ & $\begin{array}{l}-20.5 \\
-20.6 \\
-20.9 \\
-20.7\end{array}$ & $\begin{array}{l}-20.7 \\
-20.8 \\
-20.7 \\
-20.7\end{array}$ & $\begin{array}{l}-20.4 \\
-20.7 \\
-20.6 \\
-20.9\end{array}$ & $\begin{array}{l}-20.3 \\
-20.6 \\
-20.9 \\
-20.7\end{array}$ & $\begin{array}{l}+1.9 \\
-0.2 \\
+6.2 \\
+5.5\end{array}$ & $\begin{array}{l}+5.3 \\
-2.5 \\
-4.9 \\
-5.4\end{array}$ & $\begin{array}{r}+12.5 \\
+8.5 \\
+17.0 \\
+40.9\end{array}$ & $\begin{array}{r}+28.9 \\
+75.9 \\
+206.4 \\
+258.7\end{array}$ \\
\hline $\begin{array}{c}\delta^{13} \mathrm{C} \text { of worms } \\
8 \text { wk later }\end{array}$ & - & $-{ }^{a}$ & - & -23.0 & - & $-{ }^{\mathrm{a}}$ & - & +5218.2 \\
\hline \multicolumn{9}{|l|}{$\delta^{15} \mathrm{~N}$ of sediment } \\
\hline 2 wk later & +8.3 & +8.1 & +8.3 & +7.8 & +8.1 & +7.8 & +7.8 & +8.6 \\
\hline 4 wk later & +7.9 & +7.8 & +7.9 & +7.4 & +8.1 & +7.6 & +7.8 & +7.7 \\
\hline 6 wk later & +7.9 & +8.1 & +7.9 & +8.0 & +8.4 & +8.2 & +7.9 & +8.3 \\
\hline 8 wk later & +8.0 & +7.4 & +7.7 & +7.7 & +7.8 & +7.8 & +8.5 & +7.6 \\
\hline $\begin{array}{c}\delta^{15} \mathrm{~N} \text { of worms } \\
8 \text { wk later }\end{array}$ & - & $-^{\mathrm{a}}$ & - & +6.6 & - & $-{ }^{\mathrm{a}}$ & - & +8.2 \\
\hline
\end{tabular}

(mean $=$ over $50 \%$; Table 1$)$ and depressed growth (Fig. 1), probably due to a shortage of food. In the sulfide treatments, worms were cultured under the same conditions as the controls except for the daily supply of $\mathrm{Na}_{2} \mathrm{~S}$ solution to the sediment. Although even micromolar to millimolar levels of hydrogen sulfide are toxic to many aquatic organisms (Oseid \& Smith 1974a,b, Thompson et al. 1991, Vismann 1991, 1996, Bagarinao 1992), survival rates of the worms were higher (Table 1) and growth was promoted (Fig. 1). The majority of worms in the sulfide treatments reached maturity within $6 \mathrm{wk}$, and some of them reproduced, as we have observed in field populations in organically enriched areas and in laboratory colonies with ample food (Tsutsumi 1987, 1990, Tsutsumi et al. 1990). Unfortunately, we were not able to measure $\mathrm{pH}$, DO (dissolved oxygen) and hydrogen sulfide levels in the interstitial water of the sediment, and therefore we do not know how much of the AVS that we measured was in toxic form (Vissman 1996) or the exact location within the sediments of conditions suitable for chemoautotrophy. However, the higher survival rates and enhanced growth of the worms in the sulfide treatments versus controls indicate that the addition of $\mathrm{Na}_{2} \mathrm{~S}$ solution to the sediment did not have negative effects on the worms, but rather played a role in supplying additional food for them.
Because the worms were maintained in the dark, in sediment of low organic content with no addition of organic matter, we believe that the only source of organic matter available for the enhanced growth of the worms in the sulfide treatments was the organic matter produced by chemoautotrophic bacteria utilizing hydrogen sulfide. Isotopic fractionation by chemoautotrophic bacteria during carbon fixation (Degens 1969, Ruby et al. 1987, Conway et al. 1989, Conway \& McDowell-Capuzzo 1992) may be at least as large as that exhibited by phytoplankton (Goericke 1994, Fry 1996). We did not measure the $\delta^{13} \mathrm{C}$ of dissolved inorganic carbon of the sea water used for our experiments, but assume it to have been typical of average seawater, i.e., $1 \pm 1 \%$. We reasoned that organic matter produced by chemoautotrophs may have a lighter isotopic signature than that of bulk sedimentary organic matter of phytoplankton origin (Degens 1969, Ruby et al. 1987). If so, then worms that rely on chemosynthetic production should also be distinctly labeled, since the $\delta^{13} \mathrm{C}$ values of animals and their diet tend to differ by only about $1 \%$ (Michener \& Schell 1994).

In Expt 1 (Table 3), we did not determine the carbonisotope ratios of the juveniles just after settlement at the start of the experiments. However, the initial biomass derived from these juveniles should not have influenced the carbon-isotope ratios of the worms after $6 \mathrm{wk}$. The mean body dry weight of the juveniles at settlement, based on their maximum thoracic width of $0.15 \mathrm{~mm}$ (Table 4 ) was estimated to be $2.3 \mu \mathrm{g}$ (cf. Tsutsumi \& Kikuchi 1984, Tsutsumi 1987). After 6 wk, the mean body weight of the worms was similarly estimated to be $10.1 \mu \mathrm{g}$ in the controls, $68.4 \mu \mathrm{g}$ in the lowsulfide treatments, and $87.1 \mu \mathrm{g}$ in the high-sulfide treatments. Even the mean dry weight of the control worms after 6 wk was 4.4 times heavier than the juveniles at settlement.

The carbon-isotope ratios of the control worms was slightly higher (approximately $1 \%$ o for $\delta^{13} \mathrm{C}$ values) than the bulk sediment in which they fed. This increase in the $\delta^{13} \mathrm{C}$ ratio is within the range of trophic enrichment between animals and their diet (Michener \& Schell 1994). In contrast, worms in the sulfide treatments had lower $\delta^{13} \mathrm{C}$ values than the bulk sediment, 
with the values in the high-sulfide treatments being lower than those in the low-sulfide treatments. The distinctive $\delta^{13} \mathrm{C}$ signature of worms from the sulfide treatments indicates that the worms in the sulfide treatments did not utilize the same carbon source of organic matter as the control worms, even though we did not add organic matter to any of the treatments. We deduce that promotion of growth of the worms in the sulfide treatments resulted from the exploitation of organic matter that was chemosynthetically produced.

Chemosynthetic production of organic matter was, however, not detectable from $\delta^{13} \mathrm{C}$ values of the bulk sediments. In fact, sediments from all treatments were slightly enriched in ${ }^{13} \mathrm{C}$, possibly due to mineralization of ${ }^{12} \mathrm{C}$-rich organic matter. Given the relatively large pool of organic matter initially present in the sediment (approximately $9 \mathrm{~g}$ of organic carbon in the mud per container), it is unlikely that chemosynthetically produced organic matter would be detectable, unless it were either very abundant or very different, isotopically, from bulk organic matter.

In Expt 2, the results for treatments that did not receive ${ }^{13} \mathrm{C}$ amendments (Group 1 ; Table 4), were similar to those of Expt 1, i.e., the worms showed enhanced growth with $\mathrm{Na}_{2} \mathrm{~S}$ amendments and were depleted in $\delta^{13} \mathrm{C}$ relative to the sediments (Treatment 1-D). These results agree with the results of the sulfide-treated sediments and worms in Expt 1. In Treatment 2-C, in which ${ }^{13} \mathrm{C}$-labeled dissolved inorganic carbon was added to the sea water and sediments received $\mathrm{Na}_{2} \mathrm{~S}$ amendments, the stable carbon-isotope signature of sedimentary organic matter $(+40.9 \%$ after 8 wk) indicated enhanced $\mathrm{CO}_{2}$ fixation in the sediments. Thus, the chemosynthetic production that occurred in the sediments with $\mathrm{Na}_{2} \mathrm{~S}$ amendments was detectable through the isotopic enrichment of carbonate in the sea water.

By enriching the dissolved inorganic carbon with ${ }^{13} \mathrm{C}$ in Expt 2, we were able to trace the trophic processes from dissolved inorganic carbon to chemoautotrophic bacteria to Capitella sp. I. Higher $\delta^{13} \mathrm{C}$ measurements of the sediment to which $\mathrm{Na}_{2} \mathrm{~S}$ solution was added indicate the presence of chemoautotrophic bacteria (Treatments 2-C and 2-D), and the extremely high ${ }^{13} \mathrm{C}$ measurements of Capitella sp. I ( $+5218.2 \%$ in $\delta^{13} \mathrm{C}, 8 \mathrm{wk}$ later: Treatment 2-D) indicate selective utilization of that bacterial food source.

The further enrichment of ${ }^{13} \mathrm{C}$ values of sedimentary organic matter in the presence of Capitella sp. I (compare Treatments 2-C and 2-D) suggests that the burrowing or irrigation activity of the worm may stimulate sulfur-oxidizing bacteria by increasing the surface area of the $\mathrm{O}_{2} / \mathrm{S}_{2}$ interface (particle reworking and micro-environmental heterogeneity; Aller 1982). In a follow-up study (unpubl. data), we first cultured Capitella sp. I on agar plates, using a vital staining technique of bacteria with INT, 2(p-iodophenyl)-3-(pnitrophenyl)-5-phenyl tetrazolium chloride (cf. Zimmermann et al. 1978). We confirmed that bacterial activities were apparently increased around the burrow surface of the worms compared with surrounding sediments. There may be a mutualism, whereby Capitella sp. I stimulates the production of organic matter by chemoautotrophs.

We do not know the extent to which Capitella species utilize chemosynthetically produced organic matter in organically enriched sediments in the field. However, the results of our study demonstrate that Capitella sp. I shows enhanced survival and growth in enriched sulfide conditions, facilitated by its utilization of a novel source of organic matter, and in an apparently symbiotic relationship with chemoautotrophic bacteria. Although Capitella species commonly occur at extremely high densities in organically enriched sediments in coastal areas throughout the world (Pearson \& Rosenberg 1976, 1978), the reasons for their association with organically enriched sediments have remained unclear. The results of our study suggest that an additional supply of labile organic matter from chemosynthetic production may be an important factor controlling the distribution and the population dynamics of Capitella species.

Acknowledgements. Preliminary studies were done with J. P. Grassle. We acknowledge her critical reading of the manuscript and valuable comments. The paper also benefited from discussions with G. Taghon, T. Mizota, and R. Gilbert. R. H. Michener and K. Bosley performed the stable-isotope analysis. This work was supported by a Grant-in-Aid for Scientific Research of the Ministry of Education, Science, Sports and Culture, Japan, and the Mikimoto Fund for Marine Ecology.

\section{LITERATURE CITED}

Aller RC (1982) The effects of macrobenthos on chemical properties of marine sediment and overlying water. In: McCall PL, Tevesz MJS (eds) Animal-sediment relationships. Plenum, New York, p 53-102

Alongi DM, Tenore KR (1985) Effect of detritus supply on trophic relationships within experimental benthic food webs. I. Meiofauna-polychaete Capitella capitata (Type I) Fabricius) interactions. J Exp Mar Biol Ecol 88:153-166

Bagarinao T (1992) Sulfide as environmental factor and toxicant: tolerance and adaptations in aquatic organisms. Aquat Toxicol 24:21-62

Bridges TS, Levin LA, Cabrera D, Plaia G (1994) Effects of sediment amended with sewage, algae, or hydrocarbons on growth and reproduction in 2 opportunistic polychaetes. J Exp Mar Biol Ecol 177:99-119

Butman CA, Grassle JP (1992) Active habitat selection by Capitella sp-I Larvae. 1. 2-choice experiments in still water and flume flows. J Mar Res 50:669-715

Cavanaugh CM (1985) Symbioses of chemoautotrophic bacteria and marine invertebrates from hydrothermal vents and reducing sediments. Bull Biol Soc Wash 6:373-388 
Conway N, McDowell-Capuzzo J (1992) High taurine levels in the Solemya velum symbiosis. Comp Biochem Physiol B 102:175-185

Conway N, McDowell-Capuzzo J, Fry B (1989) The role of endosymbiotic bacteria in the nutrition of Solemya velum: evidence from a stable isotope analysis of endosymbionts and host. Limnol Oceanogr 34:249-255

Corliss JB, Dymond J, Gordon LI, Edmond JM, Von Herzen RP, Ballard RD, Green K, Williams D, Bainbridge A, Crane K, van Andel TH (1979) Submarine thermal springs on the Galapágos Rift. Science 203:1073-1083

Cuomo MC (1985) Sulphide as a larval settlement cue for Capitella sp I. Biogeochemistry 1:169-181

Dando PR, Hughes JA, Thiermann F (1995) Preliminary observations on biological communities at shallow hydrothermal vents in the Aegean Sea. In: Parson LM, Walker CL, Dixon DR (eds) Hydrothermal vents and processes. Geological Society, London, p 303-317 (Spec Publ No. 87)

Degens ET (1969) Biogeochemistry of stable carbon isotopes. In: Eglinton E, Murphy MJT (eds) Organic geochemistry. Springer-Verlag, Berlin, p 304-329

Felbeck H, Childress JJ, Somero GN (1981) Calvin-Benson cycle and sulphide oxidation enzymes in animals from sulphide-rich habitats. Nature 293:291-293

Felbeck H, Liebezeit G, Giere O (1983) $\mathrm{CO}_{2}$ fixation in tissues of marine oligochaetes (Phallodrilus leukodermatus and $P$. planus) containing symbiotic chemoautotrophic bacteria. Mar Biol 75:187-191

Fenchel T, Finlay BJ (1989) Kentorphoros: a mouthless ciliate with a symbiotic kitchen garden. Ophelia 30:75-93

Fry B (1996) ${ }^{13} \mathrm{C} /{ }^{12} \mathrm{C}$ fractionation by marine diatoms. Mar Ecol Prog Ser 134:283-294

Gamenick I, Abbiati M, Giere O (1998a) Field distribution and sulphide tolerance of Capitella capitata (Annelida: Polychaeta) around shallow water hydrothermal vents off Milos (Aegean Sea) A new sibling species? Mar Biol 130:447-453

Gamenick I, Vismann B, Grieshaber MK, Giere O (1998b) Ecophysiological differentiation of Capitella capitata (Polychaeta). Sibling species from different sulfidic habitats. Mar Ecol Prog Ser 175:155-166

Giere O, Wirsen CO, Schmidt C, Jannasch HW (1988) Contrasting effect of sulfide and thiosulfate on symbiotic $\mathrm{CO}_{2}$ assimilation of Phallodrilus leukodermatus (Annelida), Mar Biol 97:413-419

Goericke R (1994) Variations of marine plankton ${ }^{13} \mathrm{C}$ with latitude, temperature, and dissolved $\mathrm{CO}_{2}$ in the world ocean. Global Biochem Cycles 8:85-90

Grassle JF (1985) Hydrothermal vent animals: distribution and biology. Science 229:107-120

Grassle JF, Grassle JP (1974) Opportunistic life histories and genetic systems in marine benthic polychaetes. J Mar Res 32:253-284

Grassle JP, Grassle JF (1976) Sibling species in the marine pollution indicator Capitella (Polychaeta). Science 192: 567-569

Grassle JP, Butman CA, Mills SH (1992) Active habitat selection by Capitella sp-I larvae. 2. Multiple-choice experiments in still water and flume flows. J Mar Res 50:717-743

Hashimoto J, Miura T, Fujikura K, Ossaka J (1993) Discovery of vestimentiferan tube-worms in the euphotic zone. J Zool Sci 10:1063-1067

Jørgensen BB (1977a) Bacterial sulfate reduction within reduced microniches of oxidized marine sediments. Mar Biol 41:7-17

Jørgensen BB (1977b) Distribution of colorless sulfur bacteria (Beggiatoa spp.) in coastal marine sediments. Mar Biol 41: 19-28
Jørgensen BB, Fenchel T (1974) The sulfur cycle of a marine sediment model system. Mar Biol 24:189-201

Kamenev GM, Fadeev VI, Selin NI, Tarasov VG, Malakhov VV (1993) Composition and distribution of macro- and meiobenthos around sublittoral hydrothermal vents in the Bay of Plenty, New Zealand. NZ J Mar Freshw Res 27:407-418

Kitamori R (1975) Benthos as an environmental indicator with special reference to indicator species. In: Special Committee of the Japanese Ecological Society on environmental problems (eds) Kankyo to seibutsu shihyo. Vol 2: Aquatic environment. Kyoritsu Shuppan, Tokyo, p 265-273

Levin LA, Caswell H, Bridges T, DiBacco C, Cabrera D, Plaia G (1996) Demographic response of estuarine polychaete to pollutants: life table response experiments. Ecol Appl 6: 1295-1313

Martens CS (1984) Recycling of organic carbon near the sediment-water interface in coastal environments. Bull Mar Sci 35:566-575

Michener RH, Schell DM (1994) Stable isotpes as tracers in marine aquatic food webs. In: Lajtha K, Michener RH (eds) Stable isotopes in ecology and environmental science. Blackwell Scientific Publications, Oxford, p 138-157

Nelson DC (1992) The genus Beggiatoa. In: Balows A, Truperü HG, Dworkin M, Harder W, Schleifer KH (eds) The prokaryotes. 2nd edn. Vol IV. Springer-Verlag, New York, p 3171-3180

Oseid DM, Smith LL Jr (1974a) Chronic toxicity of hydrogen sulfide to Gammarus pseudolimnaeus. Trans Am Fish Soc $4: 819-822$

Oseid DM, Smith LL Jr (1974b) Factors influencing acute toxicity estimates of hydrogen sulfide to freshwater invertebrates. Water Res 8:739-746

Pearson TH, Rosenberg R (1976) A comparative study of the effects on the marine environment of wastes from cellulose industries in Scotland and Sweden. Ambio 5:77-79

Pearson TH, Rosenberg R (1978) Macrobenthic succession in relation to organic enrichment and pollution of the marine environment. Oceanogr Mar Biol Annu Rev 16:229-311

Peterson BJ, Fry B (1987) Stable isotopes in ecosystem studies. Annu Rev Ecol Syst 18:293-320

Rau GH (1981) Hydrothermal vent clam and tube worm ${ }^{13} \mathrm{C} /{ }^{12} \mathrm{C}$ : further evidence of nonphotosynthetic food sources. Science 213:340-342

Reish DJ (1970) The effects of varying concentrations of nutrients chlorinity and dissolved oxygen on polychaetous annelids. Water Res 4:721-735

Reish DJ (1971) Effect of pollution abatement in Los Angeles Harbours. Mar Pollut Bull 2:71-74

Reish DJ (1979) Bristle worms (Annelida: Polychaeta) In: Hart CW, Füller SH (eds) Pollution ecology of estuarine invertebrates. Academic Press, New York, p 78-125

Ruby EG, Jannasch HW, Deuser WG (1987) Fractionation of stable carbon isotopes during chemoautotrophic growth of sulfur-oxidizing bacteria. Appl Environ Microbiol 53: 1940-1943

Schmaljohann R, Faber E, Whiticar MJ, Dando PR (1990) Coexistence of methane- and sulfur-based endosymbioses between bacteria and invertebrates at a site in the Skagerrak. Mar Ecol Prog Ser 61:119-124

Tenore KR (1983) Organic nitrogen and caloric content of detritus. III. Effect on growth of a deposit-feeding polychaete, Capitella capitata. Estuar Coast Shelf Sci 17: $733-742$

Thiermann F, Akoumianaki I, Hughes JA, Giere O (1997) Benthic fauna of a shallow-water gaseohydrothermal vent area in the Aegean Sea (Milos, Greece). Mar Biol 128: $149-159$ 
Thompson BE, Bay S, Greenstein D, Laughlin J (1991) Sublethal effects of hydrogen sulfide in sediments on the urchin Lytechinus pictus. Mar Environ Res 31:309-321

Tsutsumi H (1987) Population dynamics of Capitella capitata (Polychaeta; Capitellidae) in an organically polluted cove. Mar Ecol Prog Ser 36:139-149

Tsutsumi H (1990) Population persistence of Capitella sp. (Polychaeta; Capitellidae) on a mud flat subject to environmental disturbance by organic enrichment. Mar Ecol Prog Ser 63:147-156

Tsutsumi H, Kikuchi T (1984) Study of the life history of Capitella capitata (Polychaeta: Capitellidae) in Amakusa South Japan including a comparison with other geographical regions. Mar Biol 80:315-321

Tsutsumi H, Fukunaga S, Fujita N, Sumida M (1990) Relationship between Capitella sp. and organic enrichment of the sediment. Mar Ecol Prog Ser 63:157-162

Editorial responsibility: Lisa Levin (Contributing Editor), La Jolla, California, USA
Tunnicliffe V, Juniper SK, de Burgh ME (1985) Fauna from a cold sulfur-seep in the Gulf of Mexico: comparison with hydrothermal vent communities and evolutionary implications. Bull Biol Soc Wash 6:453-464

Vetter RD (1985) Elemental sulfur in the gills of three species of clams containing chemoautotrophic symbiotic bacteria: a possible inorganic energy storage compound. Mar Biol 88:33-42

Vismann B (1991) Sulfide tolerance: physiological mechanisms and ecological implications. Ophelia 34:1-27

Vismann B (1996) Sulfide species and total sulfide toxicity in the shrimp Crangon crangon. J Exp Mar Biol Ecol 204: $131-140$

Zimmermann R, Iturriaga R, Becker-Birck J (1978) Simultaneous determination of the total number of aquatic bacteria and the number thereof involved in respiration. Appl Environ Microbiol 36:926-935

Submitted: February 16, 2000; Accepted: September 12, 2000 Proofs received from author(s): June 20, 2001 